\title{
Darwins metode
}

Sitatet over og den lille skissen som er gjengitt på forsiden av dette nummer av Tidsskriftet fanget min interesse under et besøk på en Darwin-utstilling i sommer. Charles Darwins dobbeltjubileum i 2009 - han var født 12. februar 1809 og utga On the origin of species 24 . november 1859 - har gitt hans banebrytende forskning behørig oppmerksomhet dette året. Hans verk har for øvrig alltid sporet til debatt - vitenskapelige, ideologiske og religiøse.

Det var selvsagt forskningen og funnene jeg ønsket å lære mer om da jeg besøkte utstillingen. Livsverket er imponerende. Men det som for meg var like fascinerende, var det jeg så av personen Charles Darwin. Ikke privatpersonen - selv om privatlivet var svært viktig for ham - men hans personlige egenskaper og arbeidsformen hans. Hva var det som gjorde ham til en så original og produktiv forsker?

Darwins fem år lange jordomseiling med HMS Beagle og hans funn og observasjoner på turen er velkjent. Bare ett år etter at han kom tilbake fra reisen, laget han den lille skissen som viste at han allerede hadde formulert grunnrisset til evolusjonsteorien (2). Darwin var bare 22 år gammel da han reiste ut. Da hadde han allerede et avbrutt medisinstudium og et mislykket forsøk på å utdanne seg til prest bak seg. Han reiste ikke av gårde med HMS Beagle for å «finne seg selv», men for å vie seg til naturvitenskapen. Han kom tilbake med en fabelaktig samling tegninger og notater som han bygde videre på i over 20 år før On the origin of species by means of natural selection, or the preservation of favoured races in the struggle for life ble gitt ut. Samtidig forsket han videre og publiserte en rekke bøker og artikler - helt frem til sin død. Darwin var kronisk syk hele livet og sengeliggende i lange perioder. Hvordan var det mulig for ham å oppnå så mye? Hvordan var han i stand til å gjøre så mange gode observasjoner, kombinere dem på utradisjonelt vis, komme frem til så dristige og banebrytende konklusjoner og publisere på så mange områder? Han hadde ikke hjelp av moderne teknologi eller en svær stab forskere og assistenter. Darwin arbeidet mest alene. Var han et geni som bare «så» løsninger og anstrengte seg minimalt? Ifølge ham selv var det på ingen måte slik.

Sitatet i stikktittelen er hentet fra et trebindsverk som Francis Darwin publiserte fem år etter farens død. Charles Darwin skrev en liten selvbiografisk tekst til sine barn i perioden 1876-81, uten tanke på at den skulle utgis. Han kalte den Recollections of the development of my mind and character (1). Det er altså ikke noen selvbiografi, men Darwins tanker om sin utvikling og sine forutsetninger for vitenskapelig arbeid. Det er interessant lesning, ikke minst hvis man ser den som en betraktning over hva som skal til for å bringe kunnskapen og forskningen fremover. Den likner lite på dagens debatt om forskere og forskningens kår.

Jeg velger å gjengi enkelte avsnitt av teksten her. Det passer å lese Darwins egne refleksjoner nå mot slutten av jubileumsåret. Hele teksten er for øvrig lett tilgjengelig på Internett (3).
Den rundt 70 år gamle Darwin begynner med å fortelle at han stort sett tenker, resonnerer og arbeider på samme måte som han gjorde ved starten av sin karriere. Med ett unntak - poesi, drama, bildende kunst og musikk gir ham ikke den samme gleden som før, og det beklager han: «The loss of these tastes is a loss of happiness, and may possibly be injurious to the intellect, and more probably to the moral character, by enfeebling the emotional part of our nature.»

Samtidig erkjenner han at han har oppnådd og betydd mye gjennom sin vitenskapelige gjerning og ser at det kan være «worth while to try to analyse the mental qualities and the conditions on which my success has depended; though I am aware that no man can do this correctly». Han beskriver seg selv som ganske middelmådig (!) intellektuelt sett: «I have no great quickness of apprehension or wit which is so remarkable in some clever men. (...) I am therefore a poor critic: a paper or book, when first read, generally excites my admiration, and it is only after considerable reflection that I perceive the weak points. My power to follow a long and purely abstract train of thought is very limited; and therefore I could never have succeeded with metaphysics or mathematics. My memory is extensive, yet hazy...»

Men han ser også sine sterke sider, ikke minst at han er arbeidsom og en skarp observatør: «I think that I am superior to the common run of men in noticing things which easily escape attention, and in observing them carefully. My industry has been nearly as great as it could have been in the observation and collection of facts.» Men enda viktigere er det at han brenner for vitenskapen og for å finne nye løsninger: «From my early youth I have had the strongest desire to understand or explain whatever I observed, - that is, to group all facts under some general laws. These causes combined have given me the patience to reflect or ponder for any number of years over any unexplained problem. As far as I can judge, I am not apt to follow blindly the lead of other men. I have steadily endeavoured to keep my mind free so as to give up any hypothesis, however much beloved (and I cannot resist forming one on every subject), as soon as facts are shown to be opposed to it.»

Det er nesten synd at Darwin ikke fullførte medisinstudiet. Hans åpenhet, observasjonsevne og evne til å kombinere det han iakttok ville ha gjort ham til en svært god lege og medisinsk forsker. Vel å merke hvis han hadde fått beholde sin faglige autonomi.

\section{Charlotte Haug}

redaktør

\footnotetext{
Litteratur

1. Darwin $C$. «Recollections of the development of my mind and character.» |

Darwin F, red. Life and letters of Charles Darwin, including an autobiographical chapter. London: John Murray, 1887: 26-108.

2. Lie T. Darwin og utviklingstanken. Tidsskr Nor Legeforen 2009; 129: 2325.

3. http://darwin-online.org.uk/EditorialIntroductions/Freeman_LifeandLettersand Autobiography.html (10.11.2009).
} 